\title{
Conflicts in Substance and Style in European Monetary Policy
}

According to a recent report by the news agency Reuters, the presidents of the European Central Bank and the German Bundesbank, Mario Draghi and Jens Weidmann, are no longer on speaking terms with each other. There have been rumours about a consistently deteriorating personal relationship for the last two years, but now even spokespersons for the ECB and the Bundesbank are no longer able to deny a fracture in their relationship. Draghi accuses Weidmann of being stubbornly opposed to every measure taken, while being accused himself of developing dictatorial tendencies. In October both even went so far as to bring their personal and professional conflict to the annual meeting of the International Monetary Fund and World Bank in Washington, to the consternation of other participants. This conflict between the ECB and its largest shareholder is a serious problem for the eurozone. The New York Times even went so far as to call this a threat for the common future of Europe.

The personal conflict between Draghi and Weidmann is certainly extreme, but it also stands for a broader conflict between views on monetary policy in Europe. To begin with, it is a conflict about the style of policy making. When Draghi became president of the ECB, he signalled a shift towards more transparency in communication with the public than there had been under his predecessor Jean-Claude Trichet. Draghi revealed that there were conflicting positions in the ECB Governing Council and that not everybody was in agreement with all decisions all the time. Trichet, on the other hand, had always tried to uphold the semblance of consensual decision making. Of course this was never credible and certainly not after the outbreak of the financial crisis and the highly divergent development of European economies. Draghi was more open about this and more open about the policy intentions of the ECB. He even agreed to make available edited minutes of council meetings from next year on, something observers of central banks had been demanding for years.

While Draghi was leading the ECB to become more open on the one hand, it seems that at the same time he increasingly began to rely on only a small group of council members for policy deliberations. Several times he made public announcements that had not been cleared with the ECB Council ahead of time. Allegedly, even his announcement to increase the ECB's balance sheet by another trillion euros was not discussed beforehand with a broader range of council members. This led to bad feelings and complaints not only from Jens Weidmann.

More importantly, it is not just that Weidmann feels cut out - the German government is increasingly unhappy with the way Draghi communicates. In particular, his thinly veiled critique of the German fiscal policy position in Europe at the central bankers' meeting in Jackson Hole in August led to bitterness in Berlin. At a time when he could use the support of all eurozone governments, Draghi is now at risk of isolating himself in Europe and losing what could be an important ally in his push for structural changes. As he rightly said, structural reforms and active fiscal policy in member states would make his job a lot easier.

More fundamental to the personal conflict between the two bankers than the clash in matters of style is a substantial disagreement with regard to the right policy prescription for the eurozone. In Draghi's view, the eurozone is in a deep recession, runs the risk of deflation and shows insufficient aggregate demand, with a headline inflation rate of 
only 0.4 per cent. Because of a very weak banking sector, the ECB's extremely loose monetary policy and record low interest rates have not led to an increase in lending activities and thus investments and spending. Hence the idea to directly finance firms by buying their bonds and the declared intention to even consider direct government bond buying comparable to US-style "quantitative easing". Draghi believes that doing "whatever it takes" is necessary to avoid a collapse of the eurozone, since structural reforms to improve supply conditions and a more active fiscal policy to boost aggregate demand have not been forthcoming. Implicitly, Draghi argues that he is forced to do all this because governments are not acting.

Weidmann's position instead stresses that maintaining an overly loose monetary policy for too long risks inflation and that monetary policy cannot solve structural problems. From that point of view, this kind of monetary policy violates the statutes of the ECB because direct financing of fiscal policy is explicitly forbidden. Weidmann does not support a more expansionary fiscal policy because, according to this side of the monetary policy debate, government debt is already too high; accumulating even more debt will eventually undermine monetary policy, as it increases the political pressure on the ECB. The preferred policy in this view is a focus on structural adjustment by reforming labour markets, lowering regulation and improving supply-side conditions more generally. This, obviously, is a rather long-term perspective that has little to say about immediate and short-term measures.

Weidmann's position is strengthened by the fact that the Netherlands and Austria voice a similar view. They are right, of course, that their individual economic situations do not necessarily require such an expansionary monetary policy. Moreover, Weidmann is supported by the German government. Chancellor Merkel and Finance Minister Wolfgang Schäuble are careful to avoid direct statements about monetary policy. This would be inappropriate and run against the German tradition of taking the independence of the central bank very seriously. They leave little doubt, however, that they would also rather like to see structural reforms in crisis countries and that they oppose fiscal expansion and a publicly financed increase in demand at the price of more debt.

Instead, the German government is fixated on a nominally balanced federal budget next year. German public opinion overwhelmingly shares this view and would make it difficult for Weidmann to support Draghi's course in any case. Opponents of monetary union have even sued against ECB policy at the German Constitutional Court, which duly transferred the case to the European Court of Justice. The ECJ is expected to rule in early spring next year, but whatever the outcome is, German public opinion and politicians do not seem prepared to accept that ECB policy has to look at the eurozone as a whole.

In a way, the conflict between Draghi and Weidmann reflects a similar conflict among governments. Germany's hard-line position does not resonate well with most of its European partners and is becoming more and more openly criticised by international partners. Along with the US government, international organisations like the OECD and the International Monetary Fund are asking Germany to change its fiscal course and embark on a more ambitious spending program for infrastructure, research and development, and education. Seen from this perspective, it is the German position that risks isolation in Europe as well as on the international stage. In terms of substance, it seems that Draghi has more support, though that may not be the case when it comes to style. For Draghi it would make sense to change his way of decision making and internal communication and to make more of an effort to include those who disagree with him. Then, he would not only have international encouragement but also increased support within

Carsten Hefeker, University of Siegen, Germany. the community of European central bankers. 